\title{
Determining the Impact of Contract of Employment: A Case of Low Income Earners
}

\author{
Atang Ntisa \\ Faculty of Management Sciences \\ Vaal University of Technology, Vanderbijlpark. South Africa \\ E-mail: atang@vut.ac.za \\ Jacob Selesho \\ Faculty of Management Sciences \\ Vaal University of Technology, Vanderbijlpark. South Africa \\ E-mail: jacobs@vut.ac.za
}

\section{Doi:10.5901/mjss.2014.v5n2p221}

Abstract

South African government has promised to create jobs in this democratic era; however workers continue to find themselves in unsecured or contingent labour market. As a consequence job security has captured the attention of public and private sectors since jobs are becoming scarcer than they used to be as a result of poor economic climate. Economic recession, new information technology, industrial restructuring and accelerated global competition contribute to job insecurity as employers cannot retain employees under a lifetime employment. The paper argues from the premise that without proper contract of employment the labour market will continue to fluctuate and become unstable. The survey design was used as it fit perfectly with the quantitative research approach. Target population $(N=2836)$ comprised domestic workers, while accidental sampling was chosen as it was convenient to administer questionnaires to domestic workers. Finally, questionnaires were administered to a sample of 203 (n) participants with the rate return of 202. The research was based on voluntary participation. The empirical results of this study revealed, that particular factors exist that continually maintain the vulnerability of workers in the domestic sector. These factors are: poor movement of trade unionism, employment relationships without written contracts of employment, and lack of education. This serves as a reflection of little pressure on domestic employers to comply with new labour laws that cover domestic workers

Keywords: Job security. Contract of employment. Domestic workers

\section{Background of the Study}

When South African government decided in the 1970's, to recognize statutorily Black workers who were engaged in other spheres of employment as employees, domestic workers were excluded from all Industrial Legislation. This resulted from the fact that domestic work, as an occupation, had been excluded from the definition of an employee (Strydom 2001:241).

The central issue relating to classification of employment contracts for domestic workers with regard to their job security is that their predicament being addressed on the basis of inclusion in the Basic Conditions of Employment Act (BCEA). The BCEA specifies minimum terms and conditions of employment; however this specification has created some confusion amongst employers in the domestic field (Levy 2001:1). The major problem in the domestic field is, that South Africa is experiencing ignorance of rights by management, and the correct way in which employer-employee relations should be conducted (Miles and van Rensburg, 1997).

Grossett (1994:30) and Tood (2001:40) state, that a number of reasons exist, such as the avoidance of misunderstanding and misinterpretation in respect of why the terms and conditions of employment of a domestic worker should be documented in the form of a contract of employment. Such a document ensures that neither the employee nor the employer will be able to allege that an agreement does not exist. According to Huber and Sack (1994:30), employers are not required to write a contract of employment in line with the Basic Conditions of Employment Amendment Act (Act no.75 of 1997); nevertheless, drawing up a contract of employment, is not only easier; it also forces the employer to consider issues such as overtime and leave.

The employment of domestic workers is a ubiquitous feature of South African life. It is estimated that over one 
million people are engaged in this service, comprising eleven percent of overall employment in the informal sector of the economy. At the same time, this significantly large sector of the labour market performs its work under some of the most oppressive working conditions, while experiencing a high degree of economic and physical abuse, with little or no protection from the law or society (Grant, 1997:61). One domestic worker indeed commented as follows.

'Some of the domestic workers lose their jobs as soon as the employer notices that they came under the union. Most of them, they hide that they are gone to the union. Employers know that we know they are treating us badly' (McNeil, 1989:230).

The researcher's intention in presenting the above is to provide the reader with an in-depth look at the life of domestic workers and, in this way, to create a platform from which to understand the issues that rose in this study. However, the unavailability of alternative employment and the lack of any particular skill, forces many people into this sector (Smith, 1982:167). Much information has been published on domestic workers' rights, as it has been discovered that they are exploited both economically and socially. It has been observed that domestic workers are exploited by their employers who hide behind their illiteracy (Ngidi, 2003:22).

It is against the above-mention backdrop that the central arguments to this paper are formulated. While there are some contestations regarding the mythos of job security, this study found it prudent to outline the impact of job security among the employee's. The study argue from the premise that contract of employment have a huge impact on job security, hence the paper argue from the foundation of job security.

\section{Theoretical Rationale}

The literature that underpins the current study is based upon job security as well as the job in-security; the discussion below will focus on the literature.

\subsection{Job security}

In today's world, there are many people who find themselves in the unsecured or contingent labour market. There is general agreement among labour experts that the issue of job security is likely to lead to an organizing drive by employees (Grobler, Warnich, Carrell, Elbert \& Hatfield, 2002:486). Contract of employment is one of the more common job security facilitators in all fields of employment, but also probably sometimes neglected. In the case of neglect, it may have serious consequences for the employee in terms of unhappiness, low morale, as well as for the domestic employer who may experience low productivity and turnover (Sejane, 2004). The question that arises, is whether the existence of a contract of employment, in the domestic sector, is sufficient to ensure that the above problems are not experienced? Even if such document (employment contract) does exist, what makes it effective? In order to find the answers to those and other relevant questions, a number of studies are conducted in order to determine the contributing factors to the impact of a contract of employment on the job security of domestic workers.

The dynamic nature of the South African labour market and economy, as well as the ever-changing legislative framework, put pressure on employers (Joubert, 2003:5). Today, domestic employees demand more of their jobs and respond favourably to management activities that give them greater control of their lives (Ivancevich, 1998). Employees need to have a sense of job security and want to believe that employers will not make unfair and arbitrary decisions about their employment. Further, they wish to be protected and may look to the union to ensure that their jobs are protected (Grobler et, al,. 2002:486). As a result, the need has arisen in domestic sector services to seriously look at the job security of employees.

The discrepancy between experienced and desired employment security applies to the following several categories.

$>$ The secondary segment. Workers on the "out-side" often have little or no job security, little prospect of promotion and generally poor conditions of employment. Domestic workers fall in this market, which consists of jobs that are low-paying and have unstable patterns of employment.

According to the dual labour market theory, inequality in earnings cannot be drastically reduced by investment in education and training, unless domestic workers in the secondary market are integrated through various measures into the primary labour market. This can be done, for example, through policies to reduce discrimination, better labour market information and reorienting of domestic employers (Barker, 2003:24).

Research on job security in South Africa, is fragmentary and anecdotal (Singh, 2001:68). According to Dawis and 
Lofquist in Chelladurai (1999:145), job security is a pleasurable effective condition resulting from one's appraisal of the way in which the experienced job situation meets one's needs, values and expectations. Feldman (1998:150), on the other hand, submit that job satisfaction is the mother body, which amounts to overall positive feelings that individuals have about job experiences and subsumes factors such as salary, security, achievement and challenge.

Warren (1996:41-42) states that, domestic employers need to take employment security seriously and build this concept into their professional ideology and practice. Instead of undermining job security, employers should be trying to preserve and support it in the face of destructive competitive pressures and tendencies. If secured employment cannot be supported and re-established, domestic employers will suffer. According to Redman and Mathews (1998:60-61), domestic employers need to be responsible for the retention and motivation of domestic employees. Different values and life-styles will have to be taken into account by using personnel policies to develop human resources strategies to retain domestic workers. Domestic employers with an effective employee retention program, will achieve a higher level of service quality than those without it.

According to Leonard (2000:30), domestic workers will feel secure in their careers and their commitment and effort will be increased if they obtain a sense of achievement by what they are doing and if they have some responsibilities. Similarly, if their efforts are recognized and they have a feeling of personal and career achievement or face some type of challenge, they will feel fulfilled and will perceive their work as interesting and worthwhile.

Personal factors such as individual needs, or organizational factors such as tasks and rewards, can motivate a domestic worker to engage in a specific behaviour. Motivation is transitional as well as dispositional, in that it depends on the juxtaposition of a motive trait and a suitable environment (Hanin, 2000:41). Theories of motivation can, therefore, assist domestic employers in understanding the complexities of human behaviour, as well as offering an insight into the appropriateness of the theories and their concepts to specific situations. For instance, when a domestic worker is unhappy about the nature of his/her conditions of employment, job security is in question. Maslow's and Herzberg's content of motivation theories are more relevant in addressing the issue.

The thinking of Herzberg is that individuals have to be maintained in a relatively comfortable environment in terms of safety, security and status and be developed through achievement; recognition and advancement (Grobler et al., 2002:107).

Maslow on the other hand, proposed five categories of needs in order of importance: physiological needs, safety and security needs, love and social needs, esteem needs and self-actualization needs. The value of Maslow's theory for employers in the domestic sector services is, that it emphasizes needs of domestic workers and allows their employers to work toward providing workers the means to satisfy these needs and to be more productive. Maslow's theory is of great value in a general sense, but does not apply to all people at all times (Erasmaus-Kritzinger, Bowler \& Golath, 2001:33)

Human needs must be recognized at all levels and individuals' desires must be realized. According to Kroon (1996:329), it is important that domestic employers must understand that their employees look for fair treatment and opportunities to advance and that financial gain only is not the motivator. Diale (2005:26) further states that job security comes before a high salary. It may be an incentive but not the crucial motivator that many domestic workers are driven by. Self-esteem and recognition are as important as financial gain. With regard to the above, the researcher establishes that it must be the job of domestic employers to build values and practices supporting continuous incremental improvement in the quality of domestic workers' lives to employ job security in a true sense of the word. According to Ivancevich in Surujlal (2003:106) for domestic workers to make a valuable contribution to an organization (household), they must feel that the job is right for their abilities and that they are treated equitably. Since most domestic workers, if not all, spend the majority of their working hours at work, the job becomes a major source of personal identity. According to Joubert (2003:68) the aspects which are regarded as important to management, can be described as support and commitment.

\subsection{Job insecurity}

Lack of job security can bring fear, anxiety and stress (Holmann, 1996:3). Nicholson (1998:66) indicates the following consequences of job insecurity: job insecurity is an element of attitude theory, which arises when there is an inconsistency among an individual's attitudes, behaviours, and/or values. For example, a domestic worker who strongly dislikes his/her job but who must work long hours in order to perform that job, will likely experience dissonance between intended behavior (as predicted by negative attitude) and actual behaviour (working long hours). A domestic worker who experiences cognitive dissonance will be motivated to resolve it in some fashion. For example, the worker noted above, may alter his/her attitude by focusing more on positive aspects of the work. Alternatively, the worker may alter his/her 
behaviour by working fewer hours. Prolonged periods of dissonance tend to have dysfunctional consequences for domestic employees. For example, the worker is likely to experience higher levels of stress, frustration, and anxiety. Job performance may suffer. Extreme dissonance may also cause domestic workers to withdraw from the situation by being absent more frequently or resigning altogether.

According to Cock (1984:73) lack of disability and unemployment insurance, pensions, maternity benefits and paid sick leave meant that domestic workers were extremely unsecured groups. This lack of job security is illustrated by the fact that instant dismissal was frequently resorted to by some domestic employers who often failed to observe the common law provisions relating to the issuing of notice and payment in lieu of notice.

\section{Empirical Study}

According to Knowles in Ngidi (2003:35), clues as to what people ought to learn for their own good, can be obtained from the individuals themselves. In order to achieve this aim, it is necessary to conduct a survey, based on the available literature, which forms the theoretical basis to describe the value of the contract of employment on job security. In addition, a qualitative survey in the form of structured interviews will be conducted to elicit perceptions and ideas of domestic workers on their job security. According to Boyce (2002:232), the target population is a clearly defined group of entities that have some of the characteristics relevant to the studies in common, whereas Hair, Bush and Ortinau (2002:328) view the target population as an identified group of elements that are of interest to the researcher. The target population in this study comprises domestic workers in the area of the Vanderbijlark and environment. Areas covered, include South-west 1; South-west 2; South-east 3; South-west 5; and South-west 5x1.

\subsection{Population and Sample}

It is suggested, that once the target population has been defined, the researcher must assemble a list of all eligible sampling units, which is referred to as the sample frame (Surujlal, 2003:141).

In this research a non-probability sampling method was used. Bless and Higson-Smith (1995:94) describes this sampling method as the most rudimentary one. Questionnaires were administered and interviews were conducted to the domestic workers who happened to be at the particular shopping center or bus stop at the particular time when the researcher was present for such purposes.

Accidental sampling was chosen, because it is the most convenient collection of members of the population (units of analysis) that are near and readily available for research purposes (Welman and Kruger, 2002:62). Maps and population statistics of all households in the area of Vanderbijlpark and environment, which include South-west 1, Southwest 2, South-east 3, South-west 5, and South-west 5x1, were used for selecting domestic workers who participated in the survey.

Two hundred and three participants $(n=203)$ were used in this study. It was unnecessary for all subjects to have an equal chance of being selected. The reader should note, that the sample size does not entitle the researcher to make assertions regarding job security amongst domestic workers in general. However, certain phenomenon has emerged which may be applicable or be of relevance to domestic workers at large. The researcher has, therefore, discussed the ramifications of the research findings predominantly within the parameters of the sample population $(n=203)$.

Survey research design was used in this study, which aims at the collection of qualitative data. In determining the impact of the contract of employment on the job security of domestic workers, questionnaires and structured interviews will be used. To gather information, questionnaires were distributed to various the sample groups. The survey design was chosen because it would enable the researcher to obtain accurate information from all the participants.

\subsection{Measuring instruments}

The method of data collection used in order to elicit information regarding job security, consisted of questionnaires and interviews. The questionnaires were administered to domestic workers from the identified suburbs. Closed questions were utilized in the construction of interviewing schedules. Interviews were used in cases of illiteracy as per the format of the questionnaire.

In order to investigate the accuracy or the truth of the research hypothesis of the study, there was a need to determine the dependent variable appearing (Welman and Kruger, 2002:128). Mouton, in Ngidi (2003:38-39), states that a first general principle in data collection is, that the inclusion of multiple sources of data collection in a research project, 
is likely to increase the reliability.

Prior to commencing the interview, the respondents were informed that the researcher was writing a book about domestic workers. The researcher thanked the interviewees for their participation and assured them of absolute confidentiality regarding the content of their discussions. At this point, the researcher answered any question that was posed by the respondents, and when the researcher was confident that the interviewees were comfortable with the procedure and fully understood their role, the interviews proceeded.

\subsection{Data analysis}

Once data had been collected from the above-mentioned empirical analysis, the method of continuous and descriptive statistical techniques was used to provide the researcher with the summary calculations of obtained data. All the codes were captured into the statistical program for the social sciences (SPSS), in order to elicit information from the raw data, which were sent to a statistician, who analyzed these.

\section{Results and Discussions}

Emerging themes, patterns and issues drawn from empirical data and from the literature are as follows: Job security, contract of employment, adherence to contract of employment and understanding of contracts of employment are discussed.

Results and discussions have been organised in terms of themes and issues emerging from the questionnaire. Emerging themes and issues selected and discussed are as follow.

Table 1: Contract profile

\begin{tabular}{|c|l|c|c|c|c|c|c|}
\hline \multirow{2}{*}{ Item } & \multicolumn{1}{|c|}{ Item description } & \multicolumn{2}{|c|}{ Yes } & \multicolumn{2}{|c|}{ No } & \multicolumn{2}{c|}{ N/A } \\
\cline { 3 - 7 } & & Freq & $\%$ & Freq & $\%$ & Freq & $\%$ \\
\hline 1 & Are you in possession of a contract of employment? & 39 & 57.4 & 27 & 39.7 & 2 & 2.9 \\
\hline 2 & If not, do you know where to find a copy of such a document? & 27 & 39.7 & 20 & 29.4 & 20 & 29.4 \\
\hline 3 & Did you find the contract of employment easy to review? & 53 & 77.9 & 11 & 16.2 & 3 & 4.4 \\
\hline 4 & Do you understand the language in which the contract was concluded? & 54 & 79.4 & 12 & 17.6 & 2 & 2.9 \\
\hline 5 & $\begin{array}{l}\text { If not, were some means made to interpret the contract in a language } \\
\text { understandable to you? }\end{array}$ & 16 & 23.5 & 13 & 19.1 & 34 & 50.0 \\
\hline
\end{tabular}

With regard to the above mentioned objective, it has emerged from the data, that majority of domestic workers (53\%) did not have any formal written contracts of employment. This necessitated/constituted a lack of job security, as such these workers basic conditions of employment were repudiated, as entrenched in the Basic Conditions of Employment Act. The alarming fact evident from the interviews is that the stories of domestic workers without contracts of employment are all so similar, particularly in respect of the hardships they experience. However, where they differ, is the way in which the respondents deal with and make sense of the hardships relating to domestic work. In the absence of a written document (contract of employment) detailing rights and obligations of the domestic worker, it would seem that no pressure was put on employers for them in respect of the threat of dismissal to retain the services of a domestic worker in poorly paid and hard conditions.

\subsection{Understanding conditions of employment contract}

With regard to this objective, table 1revealed that $77.9 \%$ of domestic workers with contract found the contract easy to review, while $79.4 \%$ of domestic workers with contracts indicated that they understand the language in which the contract is concluded. This is regarded more reasonable because if employer opts to conclude contracts in a language understandable to his/her employee, this will make it easy for employee to understand contents of a contract before putting his/her signature on paper.

\subsection{Adherence to terms and conditions of employment}

With regard to the above objective, the results (see table 1) of this research further revealed, that the minority of 
domestic workers (34\%) have signed contracts of employment with their employers, in which case the conditions of their employment and employment benefits were really satisfactory as compared to those having no contracts of employment. The number of domestic workers in this group indicated, that their employers adhere to the terms as stipulated in the contract and this makes them feel more secure in their employment. Such good conditions of employment and employment benefits are, for the purpose of this study, reflecting the true picture of job security.

However, Grossman (2000:27) states, that where employees are not in the possession of the copy of the contract of employment, there are exceptional instances of clear attempts by employers to significantly change aspects of an employment relationship around the issue of the contract of employment.

The research established that domestic workers experienced the following problems that require further attention and research.

$>$ A lack of trade unionization, which necessitates the insecurity of domestic workers and their vulnerability to instant dismissals on unreasonable grounds. Unlike most major occupations in the nineteenth century, domestic service was almost untouched by the growth of trade unions (Cock, 1984:75). This seems to prevail even after the 1994 elections, as was found of this study.

$>$ Illiteracy, which makes it difficult for domestic workers to interpret terms and conditions (contents) of the contract of employment before putting their signatures on the document.

$>$ Ignorance of rights by management, which put domestic workers at the back of the queue when it comes to respect, decent wages, and conditions of employment.

$>$ Most domestic workers do not sign contracts of employment with their employers on appointment, which leaves domestic workers vulnerable and without any legal position. This implies the fact, that numbers of employers in the domestic sector do not comply with the Basic Conditions of Employment Act, which creates a statutory obligation on employers whenever a domestic worker commences employment, to provide a domestic worker with written particulars that form part of the contract of employment.

On the strengths of the latter, the researcher comes to the conclusion, that the contract of employment, plus adherence to the terms by employers, is equal to job security. With this in mind, the researcher has developed recommendations in respect of the contract of employment and the job security of domestic workers.

\section{Conclusion}

Some of the domestic workers have been working for their employers for more than a year, but their employers do not regarded them as employees, because they are doing part-time jobs. The government regards part-time workers as employees who deserve to be granted basic worker rights.

The government should impose severe penalties on employers who are found with domestic workers having no contract of employment, the maximum penalty then imposed, being three thousands Rand $(R 3,000)$ or six months in jail, or both. By so doing, employers will sign contracts of employment which contain full rights and obligations of domestic workers where job security will be maintained up until date of termination of the contract of employment, in accordance with the prescribed periods.

Having signed valid contracts of employment and domestic workers then possessing copies of such contracts, will allow domestic workers to be placed firmly in the conscience of their employers. This will once and for all settle the problem of identity, profile and recognition, which domestic workers may experience with their employers.

It can be concluded, that a contract of employment could play an important role in clarifying what is to be expected from each party. The greater the clarity as to what is expected from each contractual party, the less the chance there would be for misunderstandings in the relationship. Thus, no matter how widely domestic workers are covered by labour laws in the New South Africa, and no matter the efficiency of South African labour legislation, domestic workers will continue to suffer the perception and recognition in the minds of domestic employers if they continue to form employment relationships with their employers in the absence of valid contracts of employment.

\section{References}

Barker, F. 2003. The South African labour market. $4^{\text {th }}$ ed. Pretoria: Van Schaik Publishers.

Chelladurai, P. 1999. Human resources management in sport and recreation. Champain: Human Kinetics.

Cock, J. 1984. Maids and Madams: a study in the politics of exploitation. $2^{\text {nd }}$ ed. Johannesburg: Ravan Press.

Dekker, R. 2010. Employment security: a conceptual exploration. [On line]. Available at:<http://scholar.google.co.za/scholar?hl=en\&q =employment+security>. Accessed: 26/02/2013. 
Diale, I. 2005. Money matters. City Press, p.26, 09 Jan.

Erasmus-Kritzinger, Bowler \& Goliath. 2001. Effective communication: Getting the message across in business. Lynnwood Ridge: Logo Print.

Feldman, C. 1998. Managing careers in organizations. Glenview: Scott, Foreman \& Co.

Friguglietti, R. 1989. Domestic workers: Dependency vs. self-assertiveness in the workplace. MA. Thesis. Pretoria: UP.

Gordon, S. 1973. Domestic workers: a hand book for house wives. Johannesburg: South African Institute of Race Relations.

Grant, B. 1997. Domestic workers-employees or servants. A journal about women and gender. 35(5):61-65.

Grobler, P. Warnich, S. Carrel, M. Elbert, N \& Hatfield, R. 2002. Human resources management in South Africa. $2^{\text {nd }}$ ed. Bedford Row: Thomson Learning.

Grossett, M. 1994. Your domestic worker and the law. Cape Town: Southern African Publishers.

Grossman, J. 2000. Workers and transition: an investigation of domestic workers' experience of change and continuity. [on line]. Available at:<http:www.thor.Sabinet.co.za/>. Accessed: 2/19/2004.

Hanin, Y. 2000. Emotions in sport. United States of America: Human Kinetics.

Holman, J. 1996. How to create job security in a dejobbed world. [on line]. Available at<http://www.newwork.com/Page/Opinion /Holmann/Dejobbed\%20world.html>. Accessed: 9/29/2004.

Huber, M \& Sack, P. 1994. Employing a domestic worker. $2^{\text {nd }}$. Cape Town: Metz Press.

Ivancevich, M (ed). 1998. Human resources management. $2^{\text {nd }}$ ed. New York: Irwin/McGraw-Hill.

Joubert, P. 2003. A comparison of the grievance procedure at the Vaal Triangle Technikon with the internationally accepted criteria for effective procedures. M Tech. Thesis. Vanderbilpark: Vaal Tech.

Kroon, J. (ed). 1996. General management. $2^{\text {nd }}$ ed. Mmabatho: Kagiso Tertiary.

Leonard, A. 2000. Transcending diversity: the communication manager as ethical/moral ombudsperson in the postmodern organizational setting. Journal of communicare, 19(2): 34-50.

Leung, W. 2009. Job security and productivity: evidence from academics. Berkeley, CA, 1-44.

Levy, A. 2001. Changing terms and conditions of employment. Journal of practical labour management, 10(4): 4, June.

Lincoln, E. 1999. Job security in Japan. The Brookings Review, 17(4):44-6.

McNeil, C. 1989. Contradictory forces in the domestic workers' struggle. MA. Thesis. Durban: Natal University.

Miles, M., \& van Rensburg, R. 1997. A guide to labour relations for small business. Durban: Butterworth Publishers (Pty) Ltd.

Mumford, K., \& Smith, P.N. 2004. Job tenure in Britain employee characteristics versus workplace effects. Economica, 71(282):275-297.

Ngidi, B. 2003. An assessment of the home management training needs of domestic workers in selected regions of the Ethekwini Municipal Area. M Phil. Thesis. Eastern Cape: Univ.Stellenbosch.

Nicholson, N. 1998. Blackwell writing. In: The Encyclopedic Dictionary (organizational behavior).

Redman, T \& Mathews, B. 1998. Service quality \& human resource management. Personnel Review, 27(1):57-77.

Sejane, M. 2004. Interview with Mrs Matseliso Sejane, Labour consultant, Thabure Labour Services, 26 September.

Singh, C. 2001. The job security of coaches. South African journal for research in sport, physical education and recreation, 23(1): 65-73.

Smith, D (ed). 1982. Living under "apartheid": aspects of urbanization and social change in South Africa. London: George Allen and Unwin Publishers Ltd.

Strydom, E. 2001. Essential social security law. Cape Town: Juta.

Surujlal, J. 2003. Human resources management of professional sport coaches in South Africa. D.Phil.Thesis. Johannesburg: RAU.

Tood, C. 2001. Contracts of employment. Cape Town: Siber Ink CC.

Vavi, Z. 2005. Workers' voice: Cosatu's jobs campaign continues with mass marches. City Press, p.2, 09 Oct.

Warren, R. 1996. The empty company: mobility and job security. Personnel Review, 23(6): 41-53.

Welman, J \& Kruger, S. 2002. Research methodology. $2^{\text {nd }}$ ed. Cape Town: Oxford University Press. 
